\title{
New records of amphipod crustaceans along the Israeli Mediterranean coast, including a rare Mediterranean endemic species, Maera schieckei Karaman \& Ruffo, 1971
}

\author{
Sabrina Lo Brutto $\ddagger$, Davide laciofano $\ddagger$ \\ ‡ Dept. SteBiCeF, University of Palermo, Palermo, Italy
}

\begin{abstract}
Corresponding author: Sabrina Lo Brutto (sabrina.lobrutto@unipa.it)
Academic editor: Yasen Mutafchiev

Received: 02 May 2020 |Accepted: 24 Jul 2020 | Published: 31 Jul 2020

Citation: Lo Brutto S, laciofano D (2020) New records of amphipod crustaceans along the Israeli Mediterranean coast, including a rare Mediterranean endemic species, Maera schieckei Karaman \& Ruffo, 1971 . Biodiversity Data Journal 8: e53864. https://doi.org/10.3897/BDJ.8.e53864
\end{abstract}

\begin{abstract}
Background

A survey has been carried out at four Israeli rocky sites to evaluate the diversity of the amphipod fauna on various hard substrates, still scarcely monitored, as potential pabulum for amphipod crustacean species.
\end{abstract}

\section{New information}

A survey of shallow rocky reefs along the Mediterranean coast of Israel recovered 28 species and integrated the Amphipoda checklist for the country oflsrael with 12 newlyrecorded species. Such renewed national list includes Maera schieckei Karaman \& Ruffo, 1971, a rare species endemic to the Mediterranean Sea, recorded here for the first time from the southern Levant Basin. The species, described from specimens collected in the Tyrrhenian Sea in 1970, has been only recorded eight times within the whole 
Mediterranean Sea. A revision of the bibliography on the distribution and ecology of $M$. schieckei showed that, although mentioned only for the western Mediterranean basin by some authors, it is listed in the checklist of amphipods of the Aegean Sea and neighbouring seas and has been found in the eastern Mediterranean basin since 1978 . Maera schieckei was rarely found in the Mediterranean, one of the most studied marine biogeographic region as concerns the amphipod fauna; and the species seems to prefer bays or gulf areas. The role of updating and monitoring faunal composition should be reevaluated.

\section{Keywords}

Crustacean amphipods, first records, endemism, Mediterranean Sea, Levant Sea

\section{Introduction}

The link between the variation of biodiversity over time and the change of marine environment detected nowadays is becoming a challenge for different taxonomists' communities, which aim to re-evaluate the role of taxonomy in actual and historical collections, mainly if selectively focused on specific taxa (Coll et al. 2010, Beermann and Franke 2011, Hawkins et al. 2013, Pyke and Ehrlich 2010, Scipione 2013, De-La-OssaCarretero et al. 2010, Costello et al. 2010, Costello 2020). The updating of checklists (Sorbe et al. 2002, Christodoulou et al. 2013, Ferrario et al. 2017) is now becoming the prerequisite for ecological and monitoring studies, also in the light of invasive alien species monitoring (Cao et al. 2003, Servello et al. 2019).

Many habitats often represent a sink for invasive alien species, unknown species (not yet described) or rare species. Those can be the artificial (Bonifazi et al. 2018) or biogenic (Plicanti et al. 2016, Bertocci et al. 2017) hard substrates, which can significantly influence the faunal composition especially in countries, such as Israel, where sandy and muddy bottoms show a large extension along the coast. In some cases, such scattered habitats create the favourable conditions for settlement and successive establishment, facilitating the dispersal of the species also over long distances. An example was the vermetid platforms habitat whose shape and structure favoured the settlement and successive increasing density of the lessepsian mussel Brachidontes pharaonis (P. Fisher, 1870) (Sirna Terranova et al. 2006, Rilov et al. 2004), now widespread in the eastern and central Mediterranean (Servello et al. 2019).

In the light of that, a survey has been carried out at four Israeli rocky sites to evaluate the diversity of the amphipod fauna on variegate hard substrates (e.g. rocks, bryozoans, sponges, seaweeds, coralligenous, plastic objects etc.) as potential pabulum for an establishment of amphipod crustacean species, still scarcely monitored in scattered areas of the eastern Mediterranean Sea (Lo Brutto et al. 2016, Lubinevsky et al. 2019, Sorbe et al. 2002). In European aquatic ecosystems, including the coastal Mediterranean ones, where biodiversity is changing due to climate change and the invasion of alien species, 
such a ubiquitous animal group, as amphipods, plays a crucial role in detecting such changes and deserves relevant attention as fundamental tool in monitoring biodiversity (Borja et al. 2003, Lo Brutto et al. 2013).

\section{Materials and methods}

Four shallow rocky reefs (intertidal - $25 \mathrm{~m}$ depth) off the Israeli Mediterranean coast were

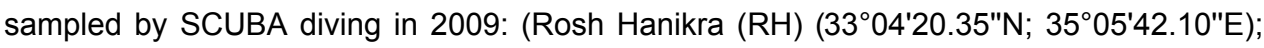
Haifa (HF) $\quad\left(32^{\circ} 48^{\prime} 47.42^{\prime \prime N}\right.$; $\left.34^{\circ} 57^{\prime} 16.15^{\prime \prime E}\right) ; \quad$ Caesarea (CS) $\quad\left(32^{\circ} 29^{\prime} 07.34^{\prime \prime N}\right.$; $\left.34^{\circ} 53^{\prime} 19.93^{\prime \prime E}\right)$ and Mikhmoret (MM) $\left(32^{\circ} 24^{\prime} 28.52^{\prime \prime N}\right.$; $\left.34^{\circ} 52^{\prime} 02.38^{\prime \prime E}\right)$ (Fig. 1). Crustaceans, hydroids, bryozoans, sponges, macrophytes and coraligenous matrices were collected and preserved in $\mathrm{EtOH} 70 \%$. Amphipods were examined under a stereomicroscope and dissected. Body length, from tip of rostrum to apex of telson, was measured using by ImageJ software after placement on graph paper and photographed (FINEPIX S1800, FUJIFILM); drawings were scanned and 'inked' using Adobe Illustrator CS5. The specimens of Maera schieckei are deposited at the Museum of Zoology "P. Doderlein" of the University of Palermo (MZPA), Italy and the Steinhardt Museum of Natural History (SMNH), Tel Aviv University, Israel.

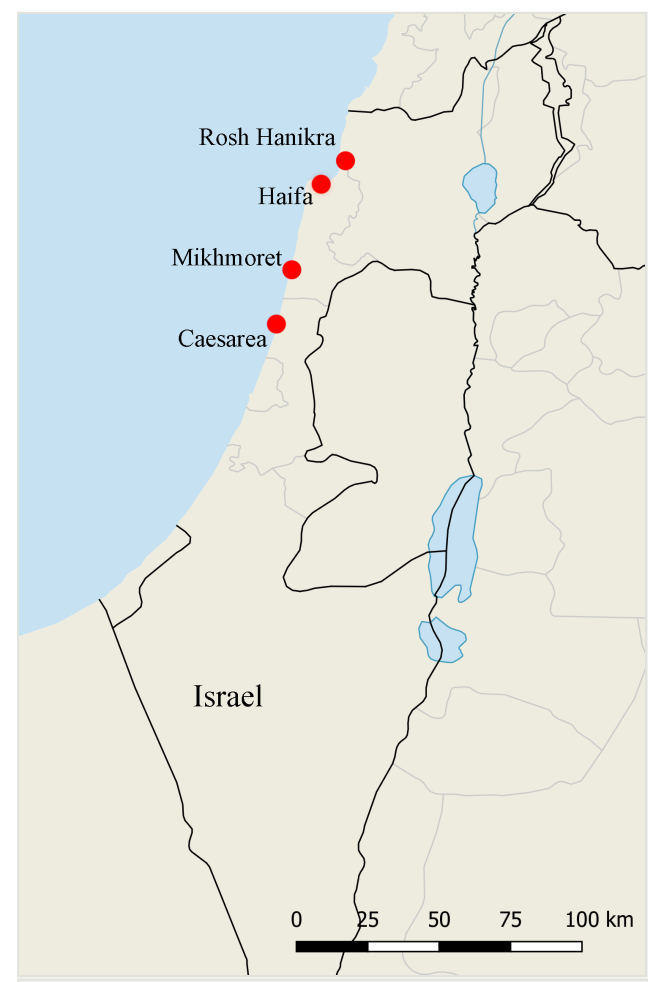

Figure 1. doi

Sample sites. 


\section{Museum collections}

Natural History Museum of Verona (NHMV), Italy: 1216-1218 Maera schieckei one holotypus, a male dissected into microslides and one male and two females, from Ischia Island, central Tyrrhenian basin. Museum of the Faculty of Fisheries of Ege University (ESFM), Turkey: ESFM-MAL/2003-2 Maera schieckei two individuals, but one heavily damaged from the Aegean coast of Turkey and ESFM-MAL/2005-1839 Maera schieckei one individual from the Levantine coast of Turkey (Bakir and Katağan 2014). Museum of Zoology "P. Doderlein" of the University of Palermo (MZPA), Italy: MZPA-AMPH-0027 Maera schieckei seven females from the coast of Israel (this paper).

\section{Data resources}

\section{Results}

A total of 3106 amphipod specimens were collected. Most specimens (88.6\%) were identified to species (Table 1), the remainder to the genus level (Ampelisca sp., $N=27$; Caprella sp., $\mathrm{N}=5$; Corophium sp., $\mathrm{N}=10$; Melita sp., $\mathrm{N}=1$; Microdeutopus sp., $\mathrm{N}=187$; Quadrimaera sp. $\mathrm{N}=24)$ or remained unclassified $(\mathrm{N}=27)$ being immature or damaged. The most abundant species were tube-dwelling: Leptocheirus guttatus $(\mathrm{N}=1227)$, Ericthonius brasiliensis $(\mathrm{N}=285)$, Ampithoe ramondi $(\mathrm{N}=260)$, Photis longicaudata $(\mathrm{N}=$ 153).

\section{Table 1.}

List of species recorded per site, with their abundance, biogeographical distribution ${ }^{1}$ and record along the Levantine coast of Turkey (Bakir et al. 2014) and Cyprus (Kocataş et al. 2001).

$\mathrm{AO}=$ Atlantic Ocean; Med= Mediterranean Sea; BS= Black Sea; RS= Red Sea; IO= Indian Ocean; $\mathrm{PO}=$ Pacific Ocean; IPO=Indo-Pacific Ocean; *First record in Israeli waters herein presented; ${ }^{1}$ References from which distribution has been inferred: Ruffo 1982, Ruffo 1989, Ruffo 1993, Ruffo 1998, Bakir et al. 2014 and Christodoulou et al. 2013.

\begin{tabular}{|c|c|c|c|c|c|c|c|}
\hline Species & $\begin{array}{l}\text { Rosh } \\
\text { Hanikra }\end{array}$ & Haifa & Mikhmoret & Caesarea & Distribution ${ }^{1}$ & Turkey & Cyprus \\
\hline $\begin{array}{l}\text { Apolochus neapolitanus (Della Valle, } \\
\text { 1893)* }\end{array}$ & & & 2 & 3 & AO-Med- IPO & Yes & No \\
\hline Ampithoe ramondi Audouin, 1826 & 1 & & 213 & 46 & $\begin{array}{l}\text { AO-Med-BS- } \\
\text { RS-IO }\end{array}$ & Yes & Yes \\
\hline $\begin{array}{l}\text { Ampithoe riedli Krapp-Schickel, } \\
\text { 1968* }\end{array}$ & & & & 18 & Med & Yes & Yes \\
\hline Leptocheirus guttatus (Grube, 1864)* & 72 & 60 & 1052 & 43 & AO-Med & Yes & Yes \\
\hline Bemlos leptocheirus (Walker, 1909)* & & & 21 & 18 & Med-IO & No & No \\
\hline Caprella equilibra Say, 1818 & & & & 12 & Cosmopolitan & No & Yes \\
\hline Phtisica marina Slabber, 1769 & & 3 & & & AO- Med-PO & Yes & Yes \\
\hline Colomastix pusilla Grube, 1861 & & 1 & & & Cosmopolitan & Yes & Yes \\
\hline
\end{tabular}




\begin{tabular}{|c|c|c|c|c|c|c|c|}
\hline Species & $\begin{array}{l}\text { Rosh } \\
\text { Hanikra }\end{array}$ & Haifa & Mikhmoret & Caesarea & Distribution ${ }^{1}$ & Turkey & Cyprus \\
\hline Dexamine spinosa (Montagu, 1813) & 4 & 22 & & & AO- Med & Yes & Yes \\
\hline $\begin{array}{l}\text { Tritaeta gibbosa (Spence Bate, } \\
\text { 1862) }\end{array}$ & 34 & & & & AO- Med & No & Yes \\
\hline $\begin{array}{l}\text { Protohyale (Boreohyale) camptonyx } \\
(\text { Heller, 1866) }\end{array}$ & & 7 & & 67 & AO-Med-RS & Yes & Yes \\
\hline $\begin{array}{l}\text { Ericthonius brasiliensis (Dana, } \\
1853)^{*}\end{array}$ & & & 154 & 131 & AO-Med-IO & No & Yes \\
\hline $\begin{array}{l}\text { Coxischyrocerus inexpectatus } \\
\text { (Ruffo, 1959) }\end{array}$ & & & & 2 & Med & Yes & No \\
\hline $\begin{array}{l}\text { Leucothoe cf. spinicarpa } \\
\text { (Abildgaard, 1789) }\end{array}$ & 2 & & & 2 & Cosmopolitan & Yes & Yes \\
\hline Lysianassa caesarea Ruffo, 1987 & 3 & 23 & 39 & 26 & Med & Yes & Yes \\
\hline $\begin{array}{l}\text { Elasmopus pectenicrus (Spence } \\
\text { Bate, 1862) }\end{array}$ & & & & 34 & $\begin{array}{l}\text { AO-Med -RS- } \\
\text { IO-PO }\end{array}$ & Yes & No \\
\hline $\begin{array}{l}\text { Elasmopus pocillimanus (Spence } \\
\text { Bate, 1862) }\end{array}$ & & & & 4 & AO-RS-IO-Med & No & Yes \\
\hline Maera grossimana (Montagu, 1808) & & & 23 & & AO-Med-BS & Yes & Yes \\
\hline $\begin{array}{l}\text { Maera schieckei Karaman \& Ruffo, } \\
\text { 1971* }\end{array}$ & 5 & 2 & & & Med & Yes & No \\
\hline $\begin{array}{l}\text { Quadrimaera inaequipes (A. Costa, } \\
1851)^{\star}\end{array}$ & 68 & 47 & 32 & 154 & Cosmopolitan & Yes & Yes \\
\hline $\begin{array}{l}\text { Perioculodes longimanus (Bate \& } \\
\text { Westwood, 1868) }\end{array}$ & & & & 10 & AO-RS-IO-Med & Yes & Yes \\
\hline $\begin{array}{l}\text { Synchelidium longidigitatum Ruffo, } \\
1947^{\star}\end{array}$ & 12 & 32 & 18 & & Med & No & No \\
\hline $\begin{array}{l}\text { Megamphopus brevidactylus Myers, } \\
1976\end{array}$ & & & & 4 & Med & No & No \\
\hline $\begin{array}{l}\text { Photis longicaudata (Spence Bate \& } \\
\text { Westwood, 1862) }\end{array}$ & 1 & & 118 & 34 & AO- Med-IO & Yes & No \\
\hline $\begin{array}{l}\text { Metaphoxus simplex (Spence Bate, } \\
\text { 1857) }\end{array}$ & 1 & 8 & 10 & 15 & AO- Med & Yes & No \\
\hline Podocerus variegatus Leach, 1814 & & & 1 & 21 & AO- Med & Yes & Yes \\
\hline $\begin{array}{l}\text { Stenothoe tergestina (Nebeski, } \\
1880)^{\star}\end{array}$ & & & & 7 & AO- Med & Yes & Yes \\
\hline Stenothoe dollfusi Chevreux, $1887^{*}$ & 5 & & & & AO- Med & No & Yes \\
\hline
\end{tabular}

The list of the 28 species (Table 1 ) integrates with the last checklist published for the whole Israeli coast by Sorbe et al. (2002) and adds 12 species not recorded yet up to now. Six are exclusively from the Mediterranean Sea, eight have been already recorded from the Mediterranean and the Atlantic Ocean and 14 have a wider distribution, including the Red Sea, the Indian and Pacific Oceans. Two amongst them are considered to have entered the Mediterranean Sea through the Suez Canal: Elasmopus pectenicrus and Bemlos leptocheirus (Marchini and Cardeccia 2017) (see Table 1 for details). Specimens of Maera 
schieckei collected at Rosh Hanikra and Haifa constitute the first recorded in the southern Levant Sea.

\section{Taxon treatment}

\section{Maera schieckei Karaman and Ruffo, 1971}

- Encyclopedia of Life https://eol.org/pages/46530501

- Catalogue of Life http://www.catalogueoflife.org/annual-checklist/2019/details/species/id/ ea87d3953b995921e521c66e0eac83a6

- World Amphipoda Database http://www.marinespecies.org/amphipoda/aphia.php? $\mathrm{p}=$ taxdetails\&id $=102825$

\section{Nomenclature}

Maera schieckei described in Karaman and Ruffo 1971: p. 132, fig. 11-13

\section{Materials}

a. scientificName: Maera schieckei Karaman and Ruffo, 1971; order: Amphipoda; family: Maeridae; subgenus: Maera; specificEpithet: schieckei; scientificNameAuthorship: Karaman and Ruffo, 1971; locationID: Rosh Hanikra; waterBody: Mediterranean Sea; country: Israel; verbatimCoordinateSystem: $33^{\circ} 04^{\prime} 20.35^{\prime \prime} \mathrm{N}, 35^{\circ} 05^{\prime} 42.10^{\prime \prime} \mathrm{E}$; eventDate: 2009 June; sex: 5 females; lifeStage: adult; catalogNumber: MZPA-AMPH-0027; recordedBy: S. Piraino; basisOfRecord: PreservedSpecimen

b. $\quad$ scientificName: Maera schieckei Karaman and Ruffo, 1971; order: Amphipoda; family: Maeridae; subgenus: Maera; specificEpithet: schieckei; scientificNameAuthorship: Karaman and Ruffo, 1971; locationID: Haifa; waterBody: Mediterranean Sea; country: Israel; verbatimCoordinateSystem: 3248'47.42"N, 3457'16.15"E; eventDate: 2009 June; sex: 2 females; lifeStage: adult; catalogNumber: MZPA-AMPH-0027; recordedBy: S. Piraino; basisOfRecord: PreservedSpecimen

\section{Description}

Body: Body slender, up to $6 \mathrm{~mm}$ long (Fig. 2A). Head: Lateral cephalic lobes rounded, antennal sinus shallow; eyes subrounded. Antenna 1 length about 1/2 body, peduncle articles 1-2 subequal, article 3 shorter; flagellum with 9 articles, shorter than peduncle; accessory flagellum with 5 articles. Antenna 2, article 3 of peduncle $2 \times$ as long as broad, article 4 longer than 5, flagellum with 5-6 articles; antennal gland cone reaching tip of peduncle article 3 . Mandibular palp article 1 with distal tooth, article 2 longer than 3. Pereon: Coxae 1-4 short, coxa 1 with anterodistal corner acutely produced. Gnathopod 1 carpus longer than propodus, propodus ovate; palm oblique, convex; dactylus with 1 anterior seta. Gnathopod 2 carpus short, propodus large, subtrapezoidal, twice as long as broad; palm with a median excavation (in male, palm slightly oblique, with deep medial excavation flanked by 2 strong teeth, defined by 2 spines and a small tooth; dactylus stout, with row of setae on anterior margin (Fig. 2B, D). Peraeopods 3-4 slender. Peraeopods 5-7 relatively slender, basis almost $2 \times$ as 
long as broad, posterodistal lobe present; dactylus half-length of propodus, nail short, anterior margin with 1-3 minute teeth. Pleon: Epimeral plates 1-2 with small posterodistal tooth. Epimeral plate 3 postero-distal corner produced with several teeth (Fig. 2C). Uropod 1 peduncle with 1 ventro-facial spine, rami subequal. Uropod 2 shorter than uropod 1, rami subequal. Uropod 3 stout, not exceeding tip of uropod 1 , peduncle as long as rami; rami subequal, 1-articulate with distal spines as long as rami. Telson nearly as long as broad, deeply cleft. Telson lobes bifurcate with 2 long distal spines (of unequal length) and 3 plumose setae.

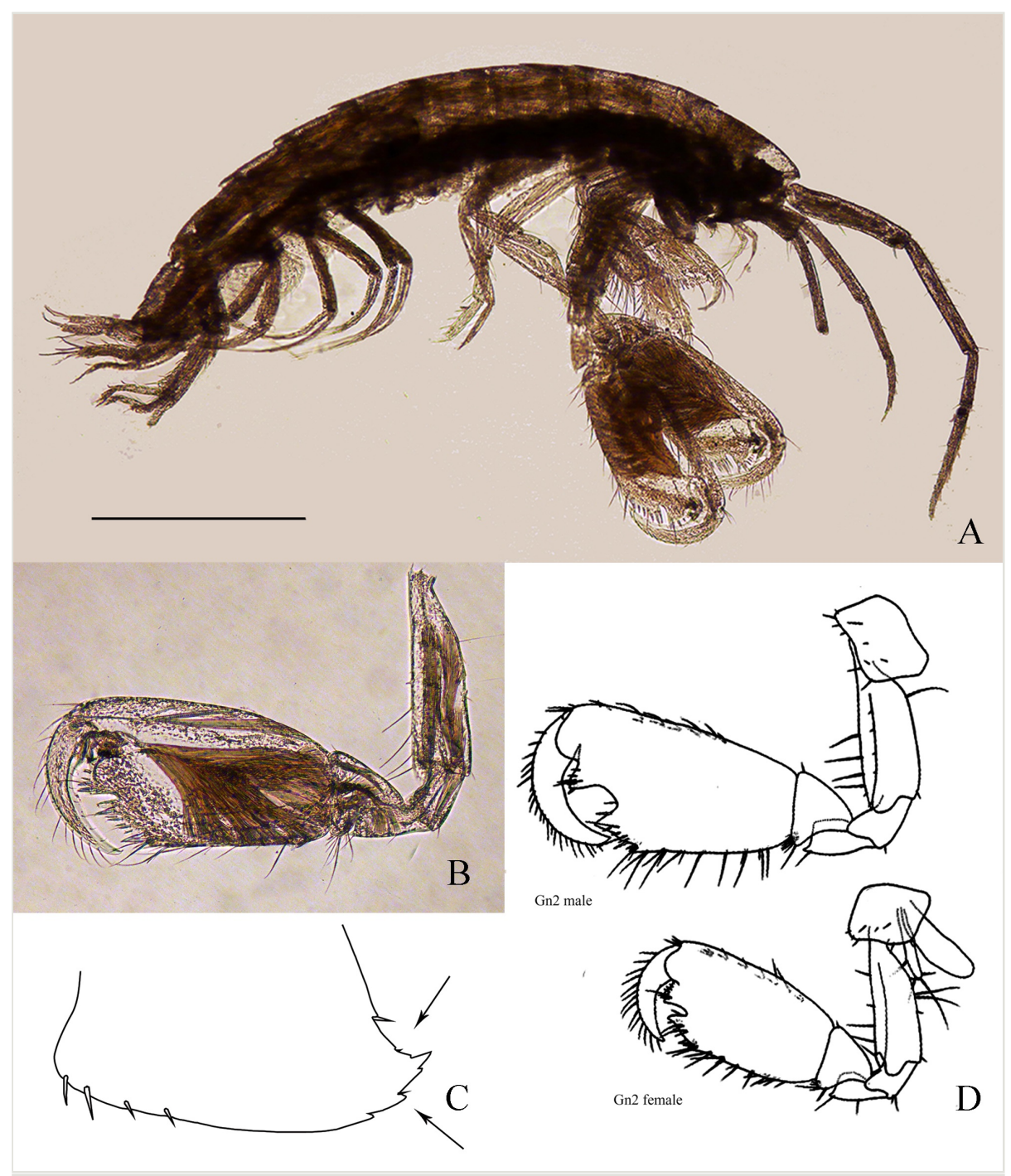

Figure 2. doi

Maera schieckei Karaman \& Ruffo, 1971; A. Lateral habitus; B. Second gnathopod female; C. Illustration of the third epimeral plate, with focus on the postero-distal corner teeth; $\mathbf{D}$. Illustration of the second gnathopod male ( $\mathrm{Gn} 2$ male) and female ( $\mathrm{Gn} 2$ female). 


\section{Distribution}

Mediterranean. Italy: Tyrrhenian Sea, Gulf of Naples (Karaman and Ruffo 1971). Spain: Menorca Channel (Junoy and Viéitez 2008). Algeria: Bay of Oran (Bakalem et al. 2014). Italy: Gulf of Castellammare (Lo Brutto 1991); Turkey: Bay of Izmir (Kocataş and Katağan 1978, Çinar et al. 2006); Anamur Bay (Bakir and Katağan 2014); Israel: Haifa Bay (Fig. 3). General: Mediterranean endemic.

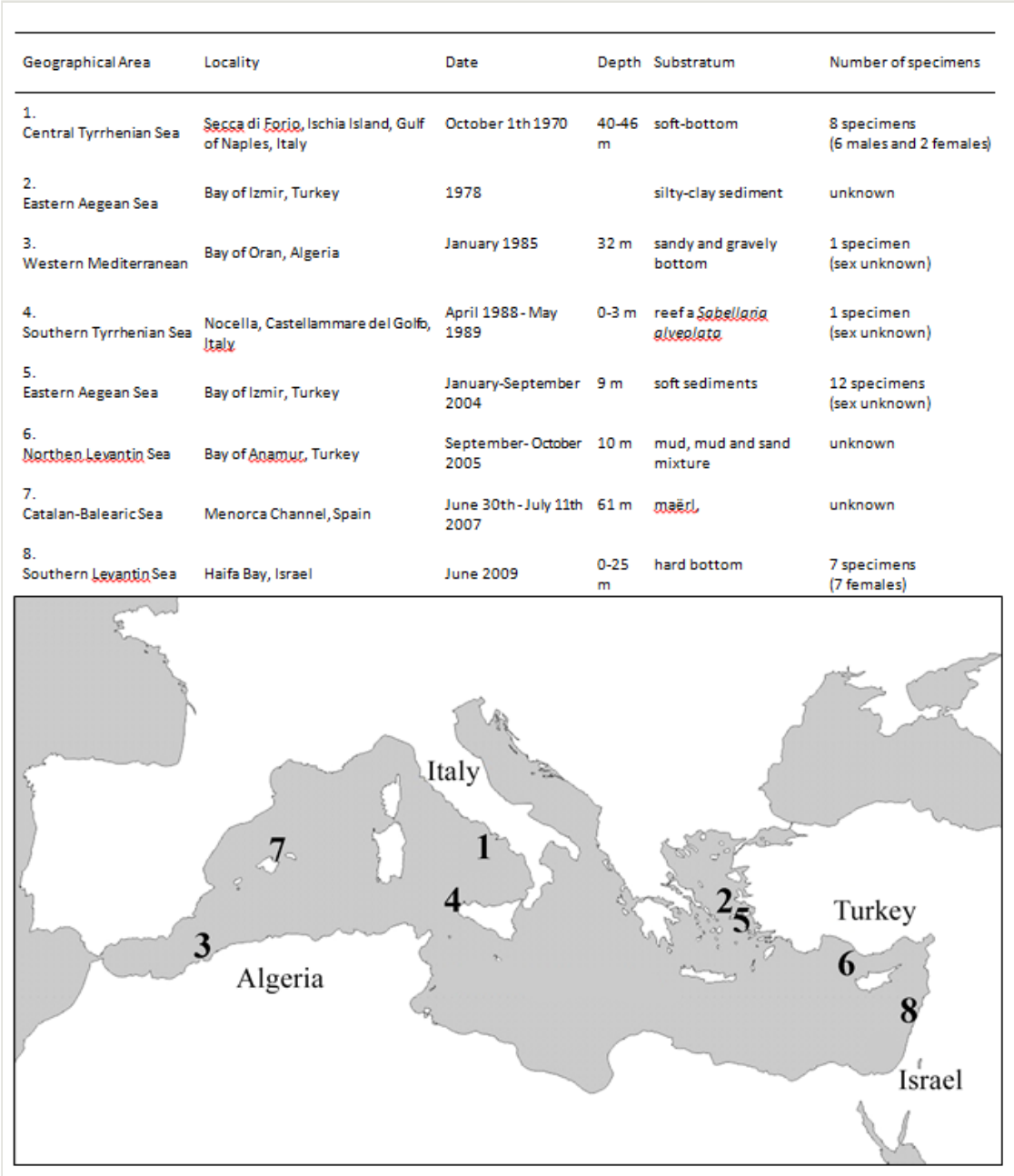

Figure 3. doi

Records of Maera schieckei in the Mediterranean Sea pointed out in the map below.

Details of the records in the Table above, from the following references: Bakalem et al. 2014, Bakir and Katağan 2014, Çinar et al. 2006, Junoy and Viéitez 2008, Karaman and Ruffo 1971, Kocataş and Katağan 1978, Lo Brutto 1991. 


\section{Notes}

Five species of Maera have been recorded in the Mediterranean Sea: M. grossimana (Montagu, 1808), M. hirondellei Chevreux, 1900, M. pachytelson Karaman \& Ruffo, 1971, M. schieckei and M. sodalis Karaman \& Ruffo, 1971 (accessed at http:// www.marinespecies.org/amphipoda on 05-04-2020). Maera schieckei is distinguished from congeneric Mediterranean species by the presence of a median U-shaped excavation in the palm of the second gnathopods and several teeth on the posterodistal corner of third epimeral plate (character not always appreciable) (Fig. 2B, C, D). The genus Maera, erected by Leach (1814), is one of the oldest amphipod genera, which has undergone extensive revision, throughout which Maera schieckei has maintained its original name and taxonomic position.

The specimens described in this study corresponds to the morphology of Maera schieckei as described by Karaman and Ruffo 1971 and available also in Ruffo (1982).

\section{Discussion}

In spite of their important ecological role within benthic ecosystems, hard bottom amphipods were rarely investigated on the Mediterranean coast of Israel compared with the soft-bottom ones (Lubinevsky et al. 2019, Lo Brutto et al. 2016, Sorbe et al. 2002).

Of the 28 amphipod species identified from the rocky reefs, 16 had been previously recorded (Sorbe et al. 2002) and 12 are new records for Israel (see Table 1), whereas 19 and 20 had been recorded off Cyprus and the Levantine coast of Turkey, respectively (Bakir et al. 2014, Kocataş et al. 2001 and references herein). Bemlos leptocheirus (Walker, 1909), occasionally recorded as Mediterranean alien species and Synchelidium longidigitatum (Ruffo, 1947), an endemic Mediterranean species, are the first records for the whole Levantine Sea.

Currently, the Mediterranean Sea suffers a high anthropogenic impact due to warming water, internal and external boat traffic and pollution (Galil 2000, Occhipinti-Ambrogi 2007). The effects of these activities can be assessed by the spread of some species, for which the hard substratum can be a point of the pathway. Several studies focused on the spread of alien species (Marchini and Cardeccia 2017, Servello et al. 2019, Ulman et al. 2017) and do not often consider the spread of the autochthonous species as an additional significant signal of changing.

The value of the Mediterranean basin in relation to its role as a hotspot of endemisms can be enhanced also by the capture of rare species. Maera schieckei is here identified for the first time along the Israeli coast and it is the most south-eastern record of the species in the Mediterranean Sea (Fig. 2). This rare Mediterranean endemic species has only been collected from a few locations, with a low number of specimens found only four times in the western basin and three times in the eastern basin (Fig. 3). The zoogeography of $M$. schieckei is scarcely known and, in some cases, inaccurate. Though Christodoulou et al. (2013) recently reported the species only present in the western Mediterranean basin and 
it was not listed in the check-list of the north Aegean Sea (Stefanidou and VoultsiadouKoukoura 1995) and Israel (Sorbe et al. 2002), this species has been identified in the eastern Mediterranean basin since 1978.

Even if this species occurred within a wide geographical range (approximatively all over the Mediterranean basin), in a wide habitat specificity (different types of substrate), it was recorded only in bay or gulf areas, often polluted and degraded areas due to the presence of commercial harbours (see references in Fig. 3); and it remains uncertain if a small-sized crustacean can spread for hundreds of kilometres along the Mediterranean basin and be recorded only few times. Studies on its life history needs to better understand dispersal and establishment. Data suggest it to be an opportunistic species. It is noteworthy to mention Ferrario et al. (2017) who evaluated the role of harbours in spreading non-native species; they can be probably significant in driving the range expansion of autochthonous species as well.

Its small populations make the species being attributed to a rarity with wide geographical range and low frequency of occurrence (Rabinowitz 1981) and the data deficiency collocating it as species Not Evaluated (NE), according to International Union for Conservation of Nature (IUCN) 2001; in this case, the IUCN recommends to give it the same degree of attention as threatened taxa, at least until the status can be assessed.

A recent estimate fixes the number of benthic amphipod species in the Mediterranean basin at 449 (Coll et al. 2010). Yet, there is no doubt that this number is an underestimate and that we lack information for wide swathes of the region as research efforts vary greatly along the coasts of the Mediterranean and even amongst particular habitats within wellstudied areas (Lo Brutto et al. 2019, Curatolo et al. 2013). A cursory examination of recent publications reveals the magnitude of the gaps. The number of species and genera new to science, some described from material collected in well-studied areas, confirm that the actual number of Mediterranean amphipods is a function of search effort and taxonomic expertise (Coleman 2015). For instance, a study along the Algerian coast listed 33 new records (Bakalem et al. 2014) and, even along the Spanish coast, a study of the shallow soft bottom fauna listed five new records and 14 second records (De-La-Ossa-Carretero et al. 2010). Records of native 'rare' species, whose role in the ecosystem and importance in bioassessment is still debated (Cao et al. 2003), accrue as well (Scipione 2013). The Marine Science Framework Directive, with its descriptors for 'good environmental status' (Review of the Commission Decision 2010/477/EU concerning MSFD criteria), opens new perspectives to monitor, manage and protect the marine environment. The three criteria for the assessment of any species are distribution, population size and population condition and special attention is called to the "integrated understanding of the distribution, extent and condition of their habitats ... to make sure that there is a sufficiently large habitat to maintain its population, taking into consideration any threat of deterioration or loss of such habitats." During an era of intensification of anthropogenic activities which drive complex and fundamental changes in the Mediterranean Sea (European Environment Agency, EEA 2015), it is important to strengthen and augment the study of the faunal diversity of the Mediterranean Sea - a sea notable for its endemisms. 


\section{Acknowledgements}

The authors are grateful to Stefano Piraino for collecting samples, to Ahmet Kerem Bakır for information on Turkish samples; to Traudl Krapp-Schickel and Bella Galil who commented on the text before submission and to an anonymous reviewer, for helpful comments.

\section{References}

- $\quad$ Bakalem A, Dauvin J, Grimes S (2014) New marine amphipod records on the Algerian coast. Journal of the Marine Biological Association of the United Kingdom 94 (4):

753-762. https://doi.org/10.1017/s0025315414000125

- Bakir AK, Katağan T (2014) Distribution of littoral benthic amphipods off the Levantine coast of Turkey with new records. Turkish Journal of Zoology 38: 23-34. https://doi.org/ 10.3906/zoo-1302-35

- $\quad$ Bakir AK, Katağan T, Aker HV, Özcan T, Sezgin M, Kocak C, Ates AS, Kirkim F (2014) The marine arthropods of Turkey. Turkish Journal of Zoology 38: 765-831.

https://doi.org/10.3906/zoo-1405-48

- $\quad$ Beermann J, Franke H (2011) A supplement to the amphipod (Crustacea) species inventory of Helgoland (German Bight, North Sea): indication of rapid recent change. Marine Biodiversity Records 4 https://doi.org/10.1017/s1755267211000388

- $\quad$ Bertocci I, Badalamenti F, Lo Brutto S, Mikac B, Pipitone C, Schimmenti E, Vega Fernández T, Musco L (2017) Reducing the data-deficiency of threatened European habitats: Spatial variation of sabellariid worm reefs and associated fauna in the Sicily Channel, Mediterranean Sea. Marine Environmental Research 130: 325-337.

https://doi.org/10.1016/j.marenvres.2017.08.008

- Bonifazi A, Mancini E, Ventura D (2018) First record of the invasive and cryptogenic species Jassa slatteryi Conlan, 1990 (Crustacea: Amphipoda) in Italian coastal waters. Journal of Sea Research 136: 37-41. https://doi.org/10.1016/j.seares.2018.03.005

- Borja A, Muxika I, Franco J (2003) The application of a Marine Biotic Index to different impact sources affecting soft-bottom benthic communities along European coasts. Marine Pollution Bulletin 46 (7): 835-845. https://doi.org/10.1016/ s0025-326x(03)00090-0

- $\quad$ Cao Y, Williams D, Williams N (2003) How important are rare species in aquatic community ecology and bioassessment? Limnology and Oceanography 43 (7): 1403-1409. https://doi.org/10.4319/lo.1998.43.7.1403

- Christodoulou M, Paraskevopoulou S, Syranidou E, Koukouras A (2013) The amphipod (Crustacea: Peracarida) fauna of the Aegean Sea, and comparison with those of the neighbouring seas. Journal of the Marine Biological Association of the United Kingdom 93 (5): 1303-1327. https://doi.org/10.1017/s002531541200183x

- Çinar ME, Katağan T, Öztürk B, Egemen Ö, Ergen Z, Kocatas A, Önen M, Kirkim F, Bakir K, Kurt G, Dagli E, Kaymakçi A, Açik S, Dogan A, Özcan T (2006) Temporal changes of soft-bottom zoobenthic communities in and around Alsancak Harbor (Izmir Bay, Aegean Sea), with special attention to the autecology of exotic species. Marine Ecology 27 (3): 229-246. https://doi.org/10.1111/j.1439-0485.2006.00102.x 
- Coleman CO (2015) Taxonomy in times of the taxonomic impediment - examples from the community of experts on amphipod crustaceans. Journal of Crustacean Biology 35 (6): 729-740. https://doi.org/10.1163/1937240x-00002381

- $\quad$ Coll M, Piroddi C, Steenbeek J, Kaschner K, Ben Rais Lasram F, Aguzzi J, Ballesteros E, Bianchi CN, Corbera J, Dailianis T, Danovaro R, Estrada M, Froglia C, Galil B, Gasol J, Gertwagen R, Gil J, Guilhaumon F, Kesner-Reyes K, Kitsos M, Koukouras A, Lampadariou N, Laxamana E, López-Fé de la Cuadra C, Lotze H, Martin D, Mouillot D, Oro D, Raicevich S, Rius-Barile J, Saiz-Salinas JI, San Vicente C, Somot S, Templado J, Turon X, Vafidis D, Villanueva R, Voultsiadou E (2010) The biodiversity of the Mediterranean Sea: Estimates, patterns, and threats. PLOS One 5 (8). https://doi.org/10.1371/journal.pone.0011842

- Costello MJ, Coll M, Danovaro R, Halpin P, Ojaveer H, Miloslavich P (2010) A census of marine biodiversity knowledge, resources, and future challenges. PLOS One 5 (8). https://doi.org/10.1371/journal.pone.0012110

- $\quad$ Costello MJ (2020) Taxonomy as the key to life. Megataxa 1 (2): 105-113. https://doi.org/10.11646/megataxa.1.2.1

- $\quad$ Curatolo T, Calvaruso C, Galil B, Lo Brutto S (2013) Geometric morphometry supports a taxonomic revision of the Mediterranean Bathyporeia guilliamsoniana (Spence Bate, 1857) (Amphipoda, Bathyporeiidae). Crustaceana 86: 820-828.

https://doi.org/10.1163/15685403-00003217

- De-La-Ossa-Carretero JA, Dauvin J, Del-Pilar-Ruso Y, Giménez-Casalduero F, Sánchez-Lizaso JL (2010) Inventory of benthic amphipods from fine sand community of the Iberian Peninsula east coast (Spain), western Mediterranean, with new records. Marine Biodiversity Records 3 https://doi.org/10.1017/s1755267210001065

- Ferrario J, Caronni S, Occhipinti-Ambrogi A, Marchini A (2017) Role of commercial harbours and recreational marinas in the spread of non-indigenous fouling species. Biofouling 33 (8): 651-660. https://doi.org/10.1080/08927014.2017.1351958

- Galil B (2000) A sea under siege-alien species in the Mediterranean. Biological Invasions 2 (2): 177-186. https://doi.org/10.1023/a:1010057010476

- Hawkins SJ, Vale M, Firth LB, Burrows MT, Mieszkowska N, Frost M (2013) Sustained observation of marine biodiversity and ecosystems. Oceanography 1: e101.

https://doi.org/10.4172/2332-2632.1000e101

- Junoy J, Viéitez JM (2008) Informe sobre los trabajos realizados en el Laboratorio de Bentos de la Universidad de Alcalá con las muestras recogidas durante la campaña CALMEN07. Convenio SGM-UAH.

- Karaman G, Ruffo S (1971) Contributo alla conoscenza delle specie mediterranee del genere Maera (Crustacea Amphipoda). Memorie del Museo Civico di Storia Naturale di Verona 9: 113-176.

- Kocataş A, Katağan T (1978) Türkiye Denizleri Littoral Bentik Amphipodları ve Yayılışları. Proje No: TBAG, 223, 63.

- Kocataş A, Katağan T, Benli H (2001) Contribution to the knowledge of the crustacean fauna of Cyprus. Israel Journal of Zoology 47 (2): 147-160. https://doi.org/10.1560/ yql8-4pbt-12w2-82hv

- $\quad$ Leach WE (1814) Article Crustaveology. In: Leach WE (Ed.) The Edinburgh Encyclopaedia. 7.

- Lo Brutto S (1991) II popolamento ad Anfipodi del Golfo di Castellammare (Sicilia, Italia meridionale) MSc Life Science. Università degli Studi di Palermo 
- Lo Brutto S, Arculeo M, Krapp-Schickel T, Ketmaier V (2013) Foreword to the Special Issue "New frontiers for monitoring European biodiversity: the role and importance of amphipod crustaceans". Crustaceana 86: 769-779.

https://doi.org/10.1163/15685403-00003204

- Lo Brutto S, laciofano D, Lubinevsky H, Galil BS (2016) Grandidierella bonnieroides Stephensen, 1948 (Amphipoda, Aoridae) -first record of an established population in the Mediterranean Sea. Zootaxa 4092 (4). https://doi.org/10.11646/zootaxa.4092.4.3

- Lo Brutto S, laciofano D, García JMG, Lubinevsky H, Galil BS (2019) Desalination effluents and the establishment of the non-indigenous skeleton shrimp Paracaprella pusilla Mayer, 1890 in the south-eastern Mediterranean. Biolnvasions Records 8 (3): 661-669. https://doi.org/10.3391/bir.2019.8.3.23

- $\quad$ Lubinevsky H, Herut B, Tom M (2019) Monitoring long-term spatial and temporal trends of the infaunal community characteristics along the shallow waters of the Mediterranean coast of Israel. Environmental Monitoring and Assessment 191 (12).

https://doi.org/10.1007/s10661-019-7872-7

- Marchini A, Cardeccia A (2017) Alien amphipods in a sea of troubles: cryptogenic species, unresolved taxonomy and overlooked introductions. Marine Biology 164 (4). https://doi.org/10.1007/s00227-017-3093-1

- Occhipinti-Ambrogi A (2007) Global change and marine communities: Alien species and climate change. Marine Pollution Bulletin 55: 342-352. https://doi.org/10.1016/ j.marpolbul.2006.11.014

- $\quad$ Plicanti A, laciofano D, Bertocci I, Lo Brutto S (2016) The amphipod assemblages of Sabellaria alveolata reefs from the NW coast of Portugal: An account of the present knowledge, new records, and some biogeographic considerations. Marine Biodiversity 47 (2): 521-534. https://doi.org/10.1007/s12526-016-0474-5

- Pyke G, Ehrlich P (2010) Biological collections and ecological/environmental research: a review, some observations and a look to the future. Biological Reviews 85 (2):

247-266. https://doi.org/10.1111/i.1469-185x.2009.00098.x

- Rabinowitz D (1981) Seven forms of rarity. In: Synge H (Ed.) The biological aspects of rare plant conservation. London, Wiley, 205-217 pp.

- Rilov G, Benayahu Y, Gasith A (2004) Prolonged lag in population outbreak of an invasive mussel: A shifting-habitat model. Biological Invasions 6 (3): 347-364.

https://doi.org/10.1023/b:binv.0000034614.07427.96

- $\quad$ Ruffo S (1982) The Amphipoda of the Mediterranean. Part 1, 13. Mémoires de l'Institut Océanographique, Monaco, I-364 pp.

- Ruffo S (1989) The Amphipoda of the Mediterranean. Part 2, 13. Mémoires de l'Institut Océanographique, Monaco, XVI-57 pp.

- $\quad$ Ruffo S (1993) The Amphipoda of the Mediterranean. Part 3, 13. Mémoires de l'Institut Océanographique, Monaco, XXIII-666 pp.

- Ruffo S (1998) The Amphipoda of the Mediterranean. Part 4, 13. Mémoires de l'Institut Océanographique, Monaco, XXVIII-950 pp.

- $\quad$ Scipione MB (2013) On the presence of the Mediterranean endemic Microdeutopus sporadhi Myers, 1969 (Crustacea: Amphipoda: Aoridae) in the Gulf of Naples (Italy) with a review on its distribution and ecology. Mediterranean Marine Science 14 (3).

https://doi.org/10.12681/mms.650

- Servello G, Andaloro F, Azzurro E, Castriota L, Catra M, Chiarore A, Crocetta F, D'Alessandro M, Denitto F, Froglia C, Gravili C, Langer M, Lo Brutto S, Mastrototaro F, 
Petrocelli A, Pipitone C, Piraino S, Relini G, Serio D, Xentidis NJ, Zenetos A (2019) Marine alien species in Italy: A contribution to the implementation of descriptor D2 of the marine strategy framework directive. Mediterranean Marine Science 20: 1-48.

https://doi.org/10.12681/mms.18711

- Sirna Terranova M, Lo Brutto S, Arculeo M, Mitton J (2006) Population structure of Brachidontes pharaonis (P. Fisher, 1870) (Bivalvia, Mytilidae) in the Mediterranean Sea, and evolution of a novel mtDNA polymorphism. Marine Biology 150 (1): 89-101.

https://doi.org/10.1007/s00227-006-0330-4

- $\quad$ Sorbe J, Basin A, Galil B (2002) Contribution to the knowledge of the Amphipoda (Crustacea) of the Mediterranean coast of Israel. Israel Journal of Zoology 48 (2): 87-110. https://doi.org/10.1560/pd7f-9710-p3kp-8uqa

- Stefanidou D, Voultsiadou-Koukoura E (1995) An account of our knowledge of the Amphipod fauna of the Aegean Sea. Crustaceana 68 (8): 597-615. https://doi.org/10.1163/156854095x01772

- Ulman A, Ferrario J, Occhipinti-Ambrogi A, Arvanitidis C, Bandi A, Bertolino M, Bogi C, Chatzigeorgiou G, Çiçek BA, Deidun A, Ramos-Esplá A, Koçak C, Lorenti M, MartinezLaiz G, Merlo G, Princisgh E, Scribano G, Marchini A (2017) A massive update of nonindigenous species records in Mediterranean marinas. PeerJ 5 https://doi.org/10.7717/ peeri. 3954 